\title{
"Financial ratios and book value of shares for selected money transfer companies listed on the Iraq Stock Exchange"
}

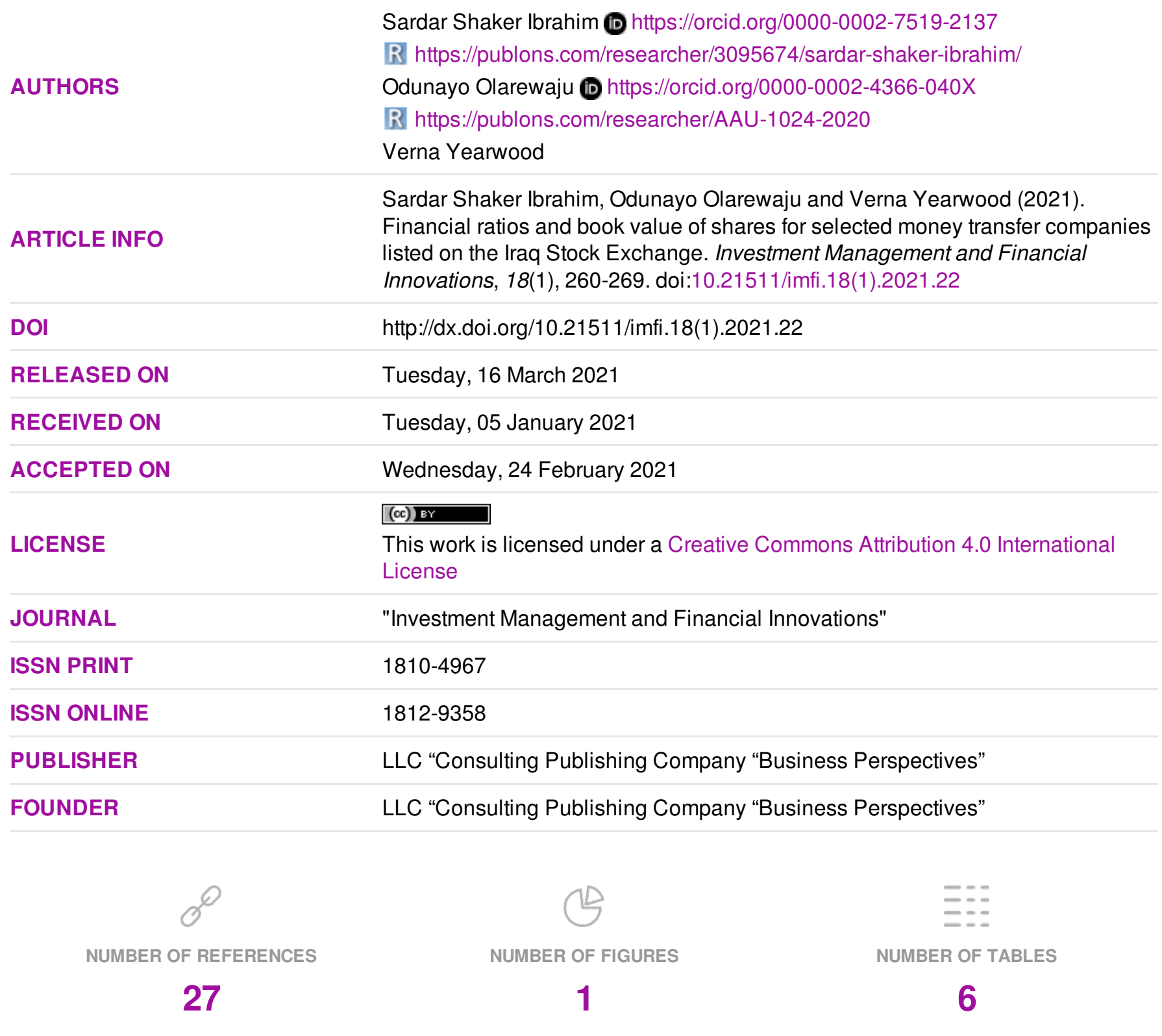

(c) The author(s) 2021. This publication is an open access article. 


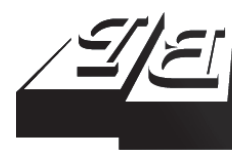

\section{BUSINESS PERSPECTIVES}

LLC "CPC "Business Perspectives" Hryhorii Skovoroda lane, 10, Sumy, 40022, Ukraine www.businessperspectives.org
Received on: $5^{\text {th }}$ of January, 2021 Accepted on: $24^{\text {th }}$ of February, 2021 Published on: $16^{\text {th }}$ of March, 2021

(C) Sardar Shaker Ibrahim, Odunayo Magret Olarewaju, Verna Yearwood, 2021

Sardar Shaker Ibrahim, Lecturer, Department of Financial and Accounting Techniques, Duhok Polytechnic University, Duhok, Iraq.

Odunayo Olarewaju, Ph.D., Senior Lecturer, Department of Management Accounting, Durban University of Technology, South Africa. (Corresponding author)

Verna Yearwood, Lecturer, Department of Management Accounting, Durban University of Technology, South Africa.

This is an Open Access article, distributed under the terms of the Creative Commons Attribution 4.0 International license, which permits unrestricted re-use, distribution, and reproduction in any medium, provided the original work is properly cited.

Conflict of interest statement: Author(s) reported no conflict of interest

Sardar Shaker Ibrahim (Iraq), Odunayo Olarewaju (South Africa), Verna Yearwood (South Africa)

\title{
FINANCIAL RATIOS AND BOOK
} VALUE OF SHARES FOR SELECTED MONEY TRANSFER COMPANIES LISTED ON THE IRAQ STOCK EXCHANGE

\begin{abstract}
The study examined the nexus between the financial ratio and book value of shares for Iraqi money transfer companies. The data used was extracted from the financial reports of selected money transfer companies listed on the Iraq Stock Exchange, and a descriptive, correlation and panel least square regression technique were adopted for the analysis. The result revealed that the financial ratio captured by earnings per share (EPS), return on investment (ROI) and return on assets (ROA) were positively related with the book value of shares (BVAL), while debt ratio (DER) was negatively related with BVAL. Also, EPS, ROA, ROI and DER positively influenced BVAL. Thus, the engagement of competent and qualified personnel to manage the assets and investments in order to ensure optimal returns is urgently required. There is also a need for proper issuing of shares by the management of money transfer companies to ensure free access to the stock market.
\end{abstract}

Keywords

JEL Classification

\section{INTRODUCTION}

Recently, book value of shares (BVAL) is essential for anyone looking to obtain money and raise capital, especially in the stock market. In view of this, it is an undeniable fact that little is known about the Iraqi financial system, but several individuals want to know how the firms' shares are valued and what is the forecast for share prices in the future (Ibrahim, 2019). Thus, long-term investment and speculation require investors to know the book value of the stocks in which the knowledge of financial ratios cannot be overemphasized. A report from the Iraq Stock Exchange (2011) showed that the number of stocks in circulation were $693,433,876$ shares, whose value was approximately 1,566,238,274 Iraqi Dinars, and the number of listed firms were 85 companies. However, the number of Iraqi firms trading on the Iraq Stock Exchange rise slightly after that year because of the essential roles the financial market played in the financial system.

The role of stock markets is very critical to the progress of any economy (Saymeh \& Salameh, 2019), but the ability to monitor the activities of a stock market effectively remains an obstacle to the huge impact of the stock market on the Iraqi economy. Financial ratio allows the comparison of different firm performance meas- 
urements in both trend and comparative analysis. Financial ratio acts as an input to predict a firm's risk, future cash flows, financial distress and credit ratings. Accurate BVAL ascertained via effective financial ratio strengthens the company's reputation and position because financial ratios are essential not only for knowing the firm's financial position, but also for analyzing and interpreting the financial evaluation and situations of the entire company.

Since the 2003 regime change and the first and second Gulf wars, Iraq has been faced with various challenges, which have made the maintenance of economic stability in the country difficult. In fact, Iraq has been unable to create a functioning stock market (Ali, 2016). Certainly, the country can build on many sectors despite the huge challenges in the areas of state administration, corruption, public sector maladministration and fighting terror. In this regard, the Iraq Stock Exchange Market is taking steps to trade actively and is encouraging corporations to get listed and trade yet again. Money transfer companies have been identified to trade on the Iraq Stock Exchange, but inefficiently. Undoubtedly, one of the causes for this limitation is inappropriate financial analysis that can resolve an efficient financial ratio. This is due to the fact that the price to book value was a good measure for the individual's investment attention because when shares are sold below the book value, it is considered undervalued, and in the opposite way, when shares are sold over the book value, it is called overvalued. Hence, there is a need to know whether the financial ratios of such earnings per shares (EPS), return on investment (ROI), return on assets (ROA) and debt ratio (DER) have an impact on BVAL for the money transfer companies listed on the Iraq Stock Exchange.

It is clear that for more than 3,000 years, money and capital have played a vital role in humans' lives, and before this period humans used the barter system as a means of transaction. It is an undeniable fact that the economy of Iraq, as a developing country, also suffered from the weak role of financial markets. Moreover, Iraqi financial markets cannot perform the required role because of the absence of the investment environment and the loss of confidence. In 2004, the Iraq Stock Exchange was established by law No. 74, which was located in Baghdad. The main purpose of establishing this market was to develop local financial sectors that positively reflected the economy of Iraq. Thus, it consisted of several companies from various sectors such as banking, insurance, industrial and investment, hotels, tourism, agricultural and service companies. However, in other countries stock markets or financial markets play a vital role in economic growth (Hussein, 2013; Hassan \& Sabah, 2019).

According to Hassan and Sabah (2019), to increase the role of financial markets and their regeneration in Iraq, some factors such as creating an appropriate environment of establishing companies and encouraging them to issue shares, allow investors to enter the stock market and encourage them to buy and sell shares of the listed companies. Raising public awareness of the importance of the market and how it works and simplifying procedures for those wishing to work through media, advertising, and others should be taken into consideration. Bratamanggala (2018) opined that issuing shares led to obtaining more capital with the belief that factors such as EPS, price to book value and ROA affected the share price. Similarly, Macharia and Gatuhi (2013) stated that as global competition increased, companies attempt to focus on issuing more shares to survive.

The Iraq Stock Exchange (2020) reported that the banking sector and money transfer companies were the most effective sectors in terms of the large volume of trading and the number of shares traded, followed by the industrial sector and its traded share prices, which are still the best prices compared to the rest of the other traded shares. Thus, it can be emphasized that cash is the most popular method of payment used by the larger percentage of individuals in the country, and a smaller percentage was observed to use credit card facilities or ATM machines. It was also noted that in Iraq and the Kurdistan region, when one needs to change currency, money transfer offices serve as an appropriate means instead of banks and other financial institutions. 


\section{LITERATURE REVIEW AND HYPOTHESIS DEVELOPMENT}

Agirman and Yilmaz (2018) examined the link between financial ratios and stock returns for 47 listed companies between 2004 and 2014 using a descriptive and regression technique. The results showed that the financial ratio was positively related with the stock returns. Thus, it was emphasized that stock returns can be predicted by financial ratios of companies under consideration. Menaje (2012) examined the influence of some selected variables, such as ROA and EPS, on price of shares in Philippines. The data used was gathered from the sample of 50 randomly selected firms quoted in Philippines and analyzed. The ordinary least square regression technique was used. The results showed that EPS was positively related with the share price, on the one hand, and on the other hand, ROA had negatively influenced the share price of the quoted firms under consideration. Hence, it implied that both ROA and EPS were good determinants of share price.

Kabajeh et al. (2012) explored the relationship between ROE, ROI, and ROA ratios and price of shares in Jordanian insurance firms from 2002 to 2007. Through descriptive and correlation analysis carried out on the data collected for the study, it was found that a direct correlation exists between both ROI and ROA with share price of the companies. Atyeh and Al-Rashed (2015) examined the link between the book value, share price and cost of capital in Kuwait. A sample of quoted Kuwaiti companies for the period of 2005 to 2011 was selected for the study. The descriptive and regression analysis carried out on the collected data from the Kuwait Stock Exchange showed that book values had an inverse relationship with share prices, while cost of capital had a positive relationship with the share price for the selected quoted companies in Kuwait.

Atidhira and Yustina (2017) analyzed the impact of ROA, DER, EPS and company size on share returns in Indonesia between 2011 and 2014. Data extracted from the financial reports of the 35 selected property and real estate industries in Indonesia was analyzed using a panel least square technique. The findings revealed that DER and EPS had a positive impact on share returns. It was further revealed that ROA and company size were negatively related with share returns of the industries under consideration. Thus, it was emphasized that the aforementioned variables determined the share return of the property and real estate industries in Indonesia. Ali et al. (2017) examined the relationship among ROA, ROCE, EPS and ROE with break-up share values of listed firms in Karachi, Pakistan, for the period 2006 to 2011. The descriptive and correlation analysis showed that all the variables except ROE were positively correlated with break-up share values. Hence, it implied that as the value of the aforementioned variables increases, the break-up share values also increase.

Wijesundera et al. (2016) empirically examined the impact of the financial ratio on stock returns of 60 listed Colombo companies between 2004 and 2013. Using the descriptive and regression analysis technique, the results indicated that the financial ratios such as ROE, EPS and Market Value/ Book Value positively related with the stock return. Thus, this provided empirical evidence for predicting stock returns using financial ratios. Shittu et al. (2016) explored the impact of price of both sales multiples and book value on the price of shares of 100 listed Nigerian firms between 2009 and 2013. The results of the random effect estimation model showed a positive relationship between the variables used for the study.

Abd et al. (2015) studied the influence of price to book value on the stock returns of listed property firms in Indonesia for the period of 2007 to 2013. A sample of 36 listed firms was used from which data was selected and analyzed using the ordinary least square regression technique. Thus, it was discovered that the price to book value significantly influenced shares. AL-Battat and ALHumaydi (2017) examined the performance indicators of the Iraq Stock Exchange compared to some of the Arab financial markets from 2003 to 2013. The data collected in the study was analyzed using descriptive analysis and ANOVA and it was found that there was a clear gap between the Iraq Stock Exchange and most of the Arab financial markets. It was further found that investment awareness was very weak among investors in some Arab stock markets, which caused high risks in 
the markets. Thus, the need existed to decrease the cost of deals so as to increase the process of stock trading operations in financial markets.

Maswadeh (2016) investigated the relationship between market value, firm's returns, and book value per share. The study was carried out on randomly selected sectors of listed Jordanian companies between 2008 and 2014. The ordinary least square regression result showed that book value per share was positively related with the market value. Hence, it was emphasized that any change in book value per share would lead to a change in the market value. Pathirawasam (2013) investigated the relevance value of earnings and book value in Sri Lanka. Data used for the study was gathered from a sample of 924 listed Sri Lanka firms from 2005 to 2009 and descriptive and correlation analysis methods were used. The result indicated that earnings were of less value than the book value of the companies under investigation. Also, it was further indicated that small companies had lower level of book value and earnings information than large companies considered in the study.

Saymeh and Salameh (2019) examined the determinants of stock services prices. A sample of 27 listed shareholding firms for the period of 2010 to 2015 was considered for the study. The analysis done using the regression technique revealed that market value of service share price was significantly affected by factors such as distributed profits, ROA and operational net cash flows. Islamoglu (2015) investigated the impact of the financial ratio on the index of the stock market among the Turkish banks between the years 2002 and 2013. In the study, a sample of 13 Turkish banks from which data was gathered and analyzed using the least square regression technique was considered. It was discovered from the results that debt to equity ratio negatively impacted the Turkish banks' index. It was further found that shareholders' equity to total assets ratio positively influenced the growth of the index stock market. Thus, it was emphasized that changes in the index of the stock market resulted from variations in financial ratios of the Turkish banks under consideration.

Hassan and Sabah (2019) examined the influence of some variables on the price of stocks indexed on the Iraq Stock Exchange over 10 years. Auto Regressive
Distributed Lag (ARDL) model was adopted for the study and the variables were cointegrated. Having established a long-run equilibrium relationship between the variables, the impact of financial ratios such as EPS, ROA, ROI and DER on book value of listed money transfer companies was examined. Generally, the redundant growth of the Iraqi stock market has piqued interest as to whether full awareness of the effect of financial analysis by investors will improve the activities of the market.

Thus, the hypotheses below should be tested:

$H_{0}: \quad$ Financial ratios do not have an effect on book value of shares for selected money transfer companies listed on the Iraq Stock Exchange.

$H_{i}$ : Financial ratios have an effect on book value of shares for selected money transfer companies listed on the Iraq Stock Exchange.

\section{RESEARCH METHOD}

Explanatory research design was used to examine the subject matter in this study. The study was carried out on randomly selected listed money transfer companies listed on the Iraq Stock Exchange. The selection of the companies was based on the availability of required and adequate information on the variables to be examined. Financial statements and annual reports were the main source of the secondary data used. A panel data of eight companies (cross section) and four years (time period) was used. The companies included: AL-Harir for money transfer (AL-HA), Alatif money transfer (ALAT), Nobles for money transfer (NOBL), Al Rabita Al Maliya for money transfer (AL-RAB), Alnoor for money transfer (ALNO), Al Nibal ALArabia for money transfer (AL-NIB), Mouta for Remittance (MOUT), and AL Manafaa for money transfer (AL-MAN).

\subsection{Model specification}

Adopting the model specified by Agirman and Yilmaz (2018), the link between financial ratios and stock returns can be stated in functional form as:

$$
S T K R_{i t}=f\left(F I N R_{i t}\right) .
$$


In a clear form, the model will be:

$$
S T K R_{i t}=\alpha_{0}+F I N R_{i t}+\mu_{i t}
$$

where $S T K R_{i t}$ - stock returns of the listed companies, FINR ${ }_{i t}$ - financial ratios of the listed companies, $\mu_{i t}$ - stochastic error term, $i$ - cross-section, $t$ - time period, and $\alpha_{0}$ - constant.

Therefore, to link the relationship between the book value (BVAL) of the money transfer companies (dependent variable) and financial ratios EPS, ROA, ROI and DER (explanatory variables), the model will be

$$
\begin{aligned}
& B V A L_{i t}=f\left(E P S_{i t}, R O A_{i t}, R O I_{i t}, D E R_{i t}\right)+ \\
& +\mu_{i t}, \\
& B V A L_{i t}=\alpha_{0}+\alpha_{1} E P S_{i t}+\alpha_{2} R O A_{i t}+ \\
& +\alpha_{3} R O I_{i t}+\alpha_{4} D E R_{i t}+\mu_{i t},
\end{aligned}
$$

where $B V A L$ - book value, $E P S$ - earnings per share, $R O A$ - return on assets, $R O I$ - return on investment, $D E R$ - debt ratio, $\mu_{i t}$ - error terms, $t$ - years (time), and $i$ - money transfer companies (cross section).

\subsection{Estimation and diagnostic techniques}

The descriptive analysis, correlation and the panel least square regression technique were used in this study. Specifically, pooled effect and fixed ef- fect estimations were used. Post-estimation tests, such as a test for the coefficient of determination,

\begin{tabular}{|c|c|c|c|c|c|}
\hline VARIABLES & BVAL & EPS & ROA & ROI & DER \\
\hline Mean & 1.015 & 0.005 & 0.005 & 0.006 & 0.044 \\
\hline Median & 1.014 & 0.005 & 0.004 & 0.004 & 0.003 \\
\hline Maximum & 1.048 & 0.029 & 0.030 & 0.042 & 0.200 \\
\hline Minimum & 0.999 & 0.000 & -0.002 & -0.004 & 0.000 \\
\hline Std. Dev. & 0.011 & 0.006 & 0.006 & 0.009 & 0.064 \\
\hline Skewness & 0.895 & 2.109 & 2.307 & 2.503 & 1.071 \\
\hline Kurtosis & 4.033 & 7.817 & 9.461 & 9.949 & 2.509 \\
\hline Jarque-Bera & 7.122 & 63.201 & 102.400 & 122.258 & 8.044 \\
\hline Probability & 0.028 & 0.000 & 0.000 & 0.000 & 0.018 \\
\hline Observations & 40 & 37 & 39 & 40 & 40 \\
\hline
\end{tabular}
T-test, standard error, F-test and probability test, were carried out.

\section{RESULTS AND DISCUSSION}

Table 1. Descriptive analysis

Table 1 showed the results of the descriptive analysis of estimating the relationship between BVAL of shares and the financial ratio of the listed money transfer companies for the period from 2013 to 2017. The financial ratio was captured by EPS, ROA, ROI and DER. The result revealed on average that BVAL, EPS, ROA, ROI and DER were $1.0149,0.0055,0.0049,0.0058$ and 0.0445 , respectively. The implication of the result is that an effort must be made to improve EPS, ROA, and ROI through an effective share price, assets and investment management to enhance better returns for the money transfer companies under considera-

Source: Researchers' compilation, 2021.

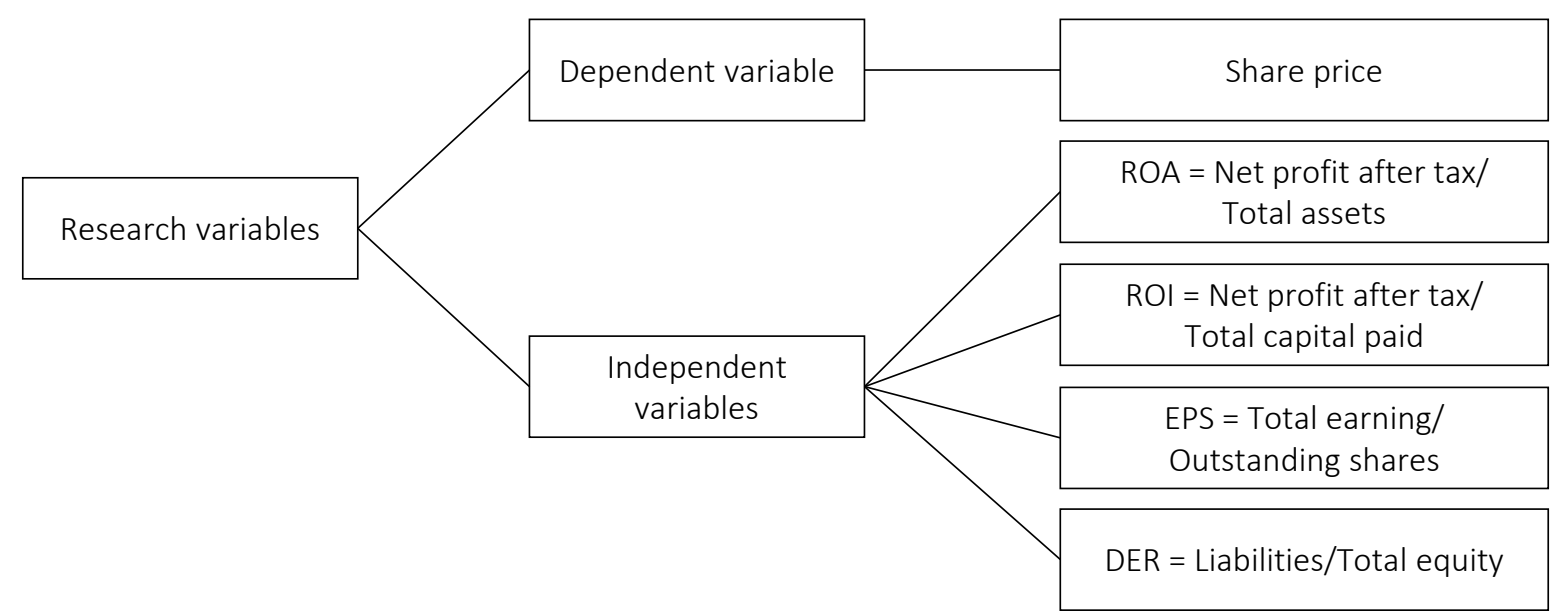

Figure 1. Explanation of dependent and independent variables 
tion. The maximum and minimum ratio for BVAL, EPS, ROA, ROI and DER were 1.048 \& $0.999,0.029$ and $0.000,0.030$ and $-0.002,0.042$ and -0.004 and 0.200 and 0.000 , respectively. The standard deviation of the ratio of $0.011,0.006,0.006,0.009$ and 0.064 indicated the rate at which BVAL, EPS, ROA, ROI and DER deviated from their respective expected ratio.

BVAL, EPS, ROA, ROI and DER were positively skewed with coefficients of $0.895,2.109,2.307$, 2.503 and 1.071, respectively, thus, a distribution with a long tail to the right is concluded. The kurtosis exhibited that BVAL, EPS, ROA and ROI with kurtosis coefficient indices of 4.033, 7.817, 9.460 and 9.949 were mesokurtic in nature, while DER with kurtosis coefficient indices of 2.510 was leptokurtic. From the coefficients of Jarque-Bera and probability values, BVAL, EPS, ROA, ROI and DER were statistically significantt in examining the relationship between the dependent and independent variables.

Table 2. Correlation matrix

\begin{tabular}{l|c:c:c:c:c}
\hline Variable & BVAL & EPS & ROA & ROI & DER \\
\hline BVAL & 1.000 & 0.841 & 0.853 & 0.766 & -0.284 \\
\hdashline EPS & 0.841 & 1.000 & 0.992 & 0.735 & -0.135 \\
\hdashline ROA & 0.853 & 0.992 & 1.000 & 0.739 & -0.191 \\
\hdashline ROI & 0.766 & 0.735 & 0.739 & 1.000 & -0.174 \\
\hdashline DER & -0.284 & -0.135 & -0.191 & -0.174 & 1.000 \\
\hline
\end{tabular}

The correlation coefficients presented in Table 2 exhibited the extent of the relationship between the variables. From this table, BVAL of money transfer companies was positively correlated with EPS, ROA and ROI with $0.84,0.85$ and 0.77 , respectively. Also, EPS was found to be positively correlated with ROA and ROI to the tune of 0.99 and 0.74 coefficients, respectively. The study also revealed a direct correlation between ROA and ROI with the correlation coefficient of 0.74 . Also, DER was neg- atively correlated with BVAL, EPS, ROA and ROI of the Iraqi money transfer companies under consideration. Thus, this implied that any continuous improvement in the financial ratio such as EPS, ROA and ROI would enhance BVAL for money transfer companies in Iraq.

The panel unit root test in Table 3 showed that all the variables were stationary at level. This was revealed as the probability of both Levin, Lin and Chu $t$ statistic values, and Augmented Dickey Fuller (ADF) test statistical values for each of the variable was less than the probability of the error margin 0.05 . This result establishes a short-run symmetry relationship between the variables.

Table 4 showed the result of the pooled, fixed and random effect panel regression to assess the relationship between BVAL and the financial ratio captured by EPS, ROA, ROI and DER for-money transfer companies in Iraq. There is a linear relationship between BVAL, EPS, ROA, ROI and DER. Specifically, the result of the panel model exhibited that the financial ratio had a both positive and negative relationship with BVAL for the selected listed money transfer companies. Thus, it was revealed that EPS, ROA and ROI were positively related with BVAL for the listed money transfer companies, while DER was negatively related with BVAL. From the pooled effect model, the result further revealed that EPS, ROA and ROI prompted a development in BVAL for the selected money transfer companies to the tune of $0.09,1.04$ and 0.37 percent, respectively, while DER was negatively related with BVAL and thus impeded the performance of the selected money transfer companies by 0.02 percent.

The results from the fixed effect estimate shows that ROA, ROI and DER were positively related with BVAL for the selected money transfer com-

Table 3. Panel unit root test

\begin{tabular}{|c|c|c|c|c|c|c|}
\hline Variable & $\begin{array}{l}\text { Levin, Lin and Chu } t^{*} \\
\text { statistic }\end{array}$ & Prob & ADF statistic & Prob & PP statistic & Prob \\
\hline BVAL & $-4.082 * * *$ & 0.0000 & $29.562 * *$ & 0.0204 & $29.842 * *$ & 0.0188 \\
\hline EPS & $-14.079 * * *$ & 0.0021 & $36.457 * * *$ & 0.0003 & $35.090 * * *$ & 0.0005 \\
\hline ROA & $-4.879 * * *$ & 0.0000 & $30.019 * *$ & 0.0179 & $27.039 * *$ & 0.0410 \\
\hline ROI & $-6.956^{* * *}$ & 0.0000 & $45.008^{* * *}$ & 0.0001 & $46.977^{* * *}$ & 0.0001 \\
\hline DER & $-5.726^{* * *}$ & 0.0000 & $36.037 * * *$ & 0.0029 & $41.440 * * *$ & 0.0005 \\
\hline
\end{tabular}

Note: $*, * *$ and $* * *$ - stationary with significance levels of $10 \%, 5 \%$ and $1 \%$, respectively. 
Table 4. Panel least square regression estimate

\begin{tabular}{|c|c|c|c|c|c|c|}
\hline \multicolumn{7}{|c|}{ Dependent variable: BVAL } \\
\hline \multirow{2}{*}{ Var } & \multicolumn{2}{|c|}{ Pooled } & \multicolumn{2}{|c|}{ Fixed } & \multicolumn{2}{|c|}{ Random } \\
\hline & Coef. & Prob. & Coef. & Prob. & Coef. & Prob. \\
\hline C & 1.007 & $0.000 * * *$ & 1.007 & $0.000 * * *$ & 1.007 & $0.000 * * *$ \\
\hline EPS & 0.092 & 0.943 & -0.336 & 0.764 & -0.199 & 0.847 \\
\hline $\mathrm{ROA}$ & 1.038 & 0.436 & 1.212 & 0.287 & 1.181 & 0.263 \\
\hline $\mathrm{ROI}$ & 0.372 & $0.024 * *$ & 0.326 & $0.013^{* *}$ & 0.367 & $0.004^{* * *}$ \\
\hline DER & -0.021 & 0.213 & 0.033 & $0.088^{*}$ & -0.001 & 0.964 \\
\hline \multicolumn{7}{|c|}{ Specification of Effects } \\
\hline & \multirow{2}{*}{\multicolumn{4}{|c|}{ Cross-section random }} & S.D. & Rho \\
\hline & & & & & 0.0026 & 0.3103 \\
\hline & \multicolumn{4}{|c|}{ Idiosyncratic random } & 0.0039 & 0.6897 \\
\hline & \multicolumn{2}{|c|}{ Pooled (Cross-section) } & \multicolumn{2}{|c|}{ Fixed (Cross-section) } & $\begin{array}{c}\text { Random } \\
\text { (Cross-section) }\end{array}$ & \\
\hline $\mathrm{AL}-\mathrm{HA}$ & \multicolumn{2}{|c|}{-} & \multicolumn{2}{|c|}{0.0045} & 0.0025 & \\
\hline ALAT & \multicolumn{2}{|c|}{-} & \multicolumn{2}{|c|}{0.0050} & 0.0036 & \\
\hline NOBL & \multicolumn{2}{|c|}{-} & \multicolumn{2}{|c|}{0.0035} & 0.0008 & \\
\hline$A L-R A B$ & \multicolumn{2}{|c|}{-} & \multicolumn{2}{|c|}{-0.0020} & -0.0020 & \\
\hline ALNO & \multicolumn{2}{|c|}{-} & \multicolumn{2}{|c|}{0.0024} & 0.0005 & \\
\hline $\mathrm{AL}-\mathrm{NIB}$ & \multicolumn{2}{|c|}{-} & \multicolumn{2}{|c|}{0.0038} & 0.0018 & \\
\hline MOUT & \multicolumn{2}{|c|}{-} & \multicolumn{2}{|c|}{-0.0055} & -0.0020 & \\
\hline AL-MAN & \multicolumn{2}{|c|}{-} & \multicolumn{2}{|c|}{-0.0117} & -0.0053 & \\
\hline$R$-squared & \multicolumn{2}{|c|}{0.7809} & \multicolumn{2}{|c|}{0.9169} & 0.7588 & \\
\hline Adjusted $R$-squared & \multicolumn{2}{|c|}{0.7535} & \multicolumn{2}{|c|}{0.8804} & 0.7286 & \\
\hline F-statistic & \multicolumn{2}{|c|}{28.521} & \multicolumn{2}{|c|}{25.091} & 25.168 & \\
\hline Prob(F-statistic) & \multicolumn{2}{|c|}{0.0000} & & & 0.0000 & \\
\hline
\end{tabular}

Note: ${ }^{* * *}$ and $* * *$ refer to significance levels at $10 \%, 5 \%$ and $1 \%$. Var stands for variable, Coef stands for coefficients, and Prob stands for the probability values.

panies and, thus, a better performance of the companies to the turn of 1.21, 0.33 and 0.03 percent, respectively, while EPS was negatively related with BVAL and thus limited the performance of the selected money transfer companies by 0.34 percent.

The random effect model showed that EPS, ROA and ROI led to an improvement in BVAL for the selected money transfer companies to the tune of 1.18 and 0.37 percent, respectively, while EPS and DER were negatively related with BVAL and thus impeded the performance of the selected money transfer companies by 0.20 and 0.001 percent, respectively. These findings contradict studies by Menaje (2012) and Atidhira and Yustina (2017), which revealed that EPS and DER were positively related with share returns. This confirmed the position of Islamoglu (2015), who previously found an inverse relationship between the stock index and debt to equity ratio. This means that there are impediments to the performance of the selected money transfer companies under consideration in Iraq.
The probability values of $0.024,0.013,0.004<0.05$ revealed that the estimated parameter of ROI for the three estimates was statistically significant in assessing the subject matter. However, the probability values $(P>0.05)$ revealed the insignificance of the estimated parameters of EPS, ROA and DER. A thorough examination of the result from fixed effect estimates based on the individual selected money transfer companies showed that the EPS, ROA, ROI and DER were positively influenced by BVAL for the AL-HA, ALAT, NOBL, ALNO and AL-NIB by $0.0046,0.0051,0.0035,0.0020$ and 0.0039 percent, respectively. Also, it was found that EPS, ROA, ROI and DER under consideration negatively affected BVAL for the AL-RAB, MOUT and AL-MAN, respectively, in Iraq money transfer companies.

The result from the random effect estimates, based on the individual selected money transfer companies, showed that ROA, ROI and DER positively influenced BVAL for the AL-HA, ALAT, NOBL, ALNO and AL-NIB to the tune of 0.0026, 0.0037, 
Table 5. Hausman test (correlated random effects)

\begin{tabular}{lc|c|c|c}
\hline \multicolumn{2}{c}{ Test summary } & Chi-Sq. statistic & Chi-Sq. d.f. & Prob. \\
\hline Random (cross-section) & & 14.966 & 4 & $0.0048^{* * *}$ \\
\hline & Random effects test comparisons (cross-section): & \\
\hline Var & Fixed & Random & Var (Diff.) & Prob. \\
\hline EPS & -0.3361 & -0.1996 & 0.1782 & 0.7465 \\
ROA & 1.2123 & 1.1813 & 0.1690 & 0.9398 \\
ROI & 0.3263 & 0.3665 & 0.0012 & 0.2463 \\
\hline DER & 0.0327 & -0.0006 & 0.0001 & $0.0027^{* * *}$ \\
\hline
\end{tabular}

Note: $*, * *$ and $* * *$ refer to significance levels at $10 \%, 5 \%$ and $1 \%$. Var stands for variable, Coef stands for coefficients, and Prob stands for the probability values.

$0.0009,0.0006$ and 0.0021 percent, respectively. Furthermore, it was revealed that money transfer companies showed that EPS, ROA, ROI and DER negatively influenced BVAL for the AL-RAB, MOUT and AL-MAN to the tune of $0.0021,0.0021$ and 0.0054 percent, respectively, in Iraqi money transfer companies. The idiosyncratic random error term having a rho value of 0.689 indicates a strong correlation between the cross-sectional error term and the individually selected companies.

$0.754,0.880$ and 0.7287 as the adjusted R-squared for the three estimates (pooled, fixed and random effect) exhibited that $75.4,88.0$ and 72.9 percent variation in the book value of shares for the selected money transfer companies in Iraq can be explained by the financial ratio captured by EPS, ROA, ROI and DER under consideration. Thus, it implies EPS, ROA, ROI and DER enhance BVAL for money transfer companies. Overall, the probability values of the F- statistics of $0.000,0.000$ and 0.000 , which is less than 0.05 , is an indication that all the estimates were statistically significant. Thus, the estimations were reliable, valid and appropriate for assessing the impact of financial ratios on BVAL for the selected money transfer companies in Iraq.

Hausman test result is shown in Table 5. The chisquare value 14.966 is greater than 9.488 , and 0.0048 probability value is greater than 0.05 . This means that the random effect estimate was consistent with the impact of the financial ratio on the book value of money transfer companies. Thus, the random effect estimate was better than the fitted fixed effect estimate, hence it was preferred. This made a random effect estimate when examining the impact of the financial ratio on BVAL for the money transfer companies selected for this study. Thus, the fact that the random effect model was found to be the most reliable, consistent, efficient and sufficient, led to the residual cross-sectional dependence (CD) test presented in Table 6.

\section{Table 6. Residual CD test}

\begin{tabular}{|c|c|c|c|}
\hline \multicolumn{4}{|c|}{$H_{0}:$ There is no $C D /$ correlation in the weighted residual } \\
\hline \multicolumn{4}{|l|}{ Period: 5} \\
\hline \multicolumn{4}{|l|}{ Cross-sections: 8} \\
\hline \multicolumn{4}{|c|}{ Total observations (balanced): 37} \\
\hline Test & Statistic & d.f. & Prob. \\
\hline Breusch-Pagan LM & 33.030 & 28 & 0.235 \\
\hline Pesaran scaled LM & -0.396 & & 0.692 \\
\hline Pesaran CD & 1.102 & & 0.271 \\
\hline
\end{tabular}

Note: $* * *$ and $* * *$ refer to significance levels at $10 \%, 5 \%$ and $1 \%$. Var stands for variable, Coef stands for coefficients, Prob stands for the probability values.

Table 6 shows the result of the residual CD of Breusch-Pagan LM, Pesaran scale LM and Pesaran CD. Thus, the values of $33.030,-0.397$ and 1.102 , respectively, with the corresponding probabilities values of $0.235,0.692$ and 0.271 greater than 0.05 exhibited the acceptance of no CD. Hence, this suggests that there was CD between the financial ratios, such as EPS, ROA, ROI and DER, and BVAL for the money transfer companies in Iraq.

\section{CONCLUSION}

An investigation of the impact of financial ratios on BVAL for the selected money transfer companies as revealed by the random effect model showed that ROA and ROI led to an improvement in BVAL for the selected money transfer companies. It was found that EPS and DER were negatively related with 
BVAL. Post-estimation tests revealed that ROI had a great effect on the book value of money transfer companies and thereby enhanced the performance of Iraqi money transfer companies. The heterogeneity study of the selected money transfer companies revealed that financial ratios, such as EPS, ROA, ROI and DER, positively influenced BVAL, particularly for AL-HA, ALAT, NOBL, ALNO and AL-NIB as money transfer companies. Furthermore, it was found that money transfer companies showed that EPS, ROA, ROI and DER negatively influenced BVAL for AL-RAB, MOUT and AL-MAN, respectively, in Iraqi money transfer companies.

Thus, it can be concluded that the management of money transfer companies must engage competent and qualified personnel to manage their assets and investments in order to ensure optimal returns. Information asymmetry should be minimal, and access to markets should be widened in such a way as to encourage investors and to be able to trade on the stock market. Operational efficiency, stability, profitability and liquidity give investors more pertinent information about companies. This allows analysts and investors to gain lucrative advantages in the stock market using widely accepted and debatably essential ratio analysis techniques.

\section{AUTHOR CONTRIBUTIONS}

Conceptualization: Sardar Shaker Ibrahim.

Data curation: Sardar Shaker Ibrahim.

Formal analysis: Odunayo Olarewaju.

Investigation: Odunayo Olarewaju.

Methodology: Odunayo Olarewaju.

Resources: Verna Yearwood.

Software: Verna Yearwood.

Supervision: Odunayo Olarewaju.

Validation: Sardar Shaker Ibrahim, Verna Yearwood.

Writing - original draft: Sardar Shaker Ibrahim.

Writing - review \& editing: Verna Yearwood.

\section{REFERENCES}

1. Abd. Majid, M. S., \& Benazir, B. (2015). An indirect impact of the price to book value to the stock returns: an empirical evidence from the property companies in Indonesia. Jurnal Akuntansi dan Keuangan Universitas Kristen Petra, 17(2), 91-96. https://doi org/10.9744/jak.17.2.91-96_

2. Agirman, E., \& Yilmaz, O. (2018). Value of financial ratios in predicting stock returns: a study on Borsa Istanbul (BIST). Journal of Business, Economics and Finance (JBEF), 7(2), 191-199. Retrieved from http://www.pressacademia. org/archives/jbef/v7/i2/6.pdf_

3. AL-Battat, M. F. S., \& ALHumaydi, T. S. D. (2017). Evaluating the performance of Iraq stock exchange in comparison to some financial markets for the period 2003-2013. Economic Science, 12(46), 92-103. Retrieved from https://www.iasj.net/ iasj?func $=$ fulltext\&aId $=142565$.

4. Ali, B. J. (2016). Iraq Stock Market and its Role in the Economy. Retrieved from https://www.amazon.com/Iraq-Stock-Market-RoleEconomy/dp/3659634271

5. Ali, M. A., Kalim, U., Raza, H., Ali, H. A., Rehman, M., \& Ullah M. I. (2017). The Relationship Between ROA, ROE, ROCE and EPS Ratios with Break-up Values of Shares of Karachi-Pakistan Fuel and Energy Listed Companies. Journal of Finance and Accounting, 5(3), 115122. https://doi.org/10.11648/j. jfa.20170503.15

6. Annual reports of Iraqi money transfer firms. Available at http://www.isxiq.net/isxportal/ portal/companyGuideList.html. (Accessed 4 April 2020).

7. A report about Iraq financial market. Retrieved from http:// www.ikhnews.com/index. php? page $=$ article \&id $=15921$. (Accessed 6 April 2020).

8. Arab Monetary Fund. (2014). The Performance of Arab Stock Markets. Quarterly Bulletin, 77, 3. Retrieved from https://www.amf. org.ae/en

9. Atyeh, M. H., \& Al-Rashed, W. (2015). Correlation among Cost of Capital, Book Values and Shares Prices: The Case of Kuwait Listed Companies. Journal of Economics, Business and Management, 3(1), 136-139. https://doi.org/10.7763/ JOEBM.2015.V3.169 
10. Atidhira, A. T., \& Yustina, A. I. (2017). The influence of return on assets, debt to equity ratio, earnings per share and company size on share return in property and real estate companies. Journal of Applied Accounting and Finance, 1(2), 128-145. http://dx.doi. org/10.33021/jaaf.v1i2.363

11. Bratamanggala, R. (2018). The Factors Affecting Board Stock Price of Lq45 Stock Exchange 2012-2016: Case of Indonesia. European Research Studies Journal, O(1), 115-124. https://doi. org/10.35808/ersj/934

12. Geetha, E., \& Swaaminathan, T. M. (2015). Study on the factors influencing stock price a comparative study of automobile and information technology industries stocks in India. International Journal of Current Research and Academic Review, 3(3), 97-109. Retrieved from www. ijcrar.com.

13. Hussein, M. A. (2013). Securities and their markets, with reference to the Iraq Stock Exchange, a theoretical framework. Journal of University of Babylon, 21(1), 64-80. Retrieved from https://www.iasj. net/iasj?func $=$ article $\&$ aId $=77331$

14. Hassan, K. G., \& Sabah, W. (2019). Measuring the impact of some macroeconomic variables on the stock price index in the Iraq stock exchange for the period (2006-2015). Academic Journal of Nawroz University (AJNU), 8(4), 93-106. https://doi.org/10.25007/ ajnu.v8n4a441

15. Ibrahim, S. S. (2017). The Impacts of Liquidity on Profitability in Banking Sectors of Iraq. International Journal of Finance \& Banking Studies, 6(1), 113-121. https://doi.org/10.20525/ijfbs. v6i1.650.

16. Ibrahim, S. S. (2019). The Impacts of Capital Structure on Bank Performance. Koya University Journal of Humanities and Social Sciences, 2(1), 118-123. https://doi. org/10.14500/kujhss.v2n1y2019. pp118-123.

17. Islamoglu, M. (2015). Predictive power of financial ratios with regard to the Turkish banking industry: an empirical study on the stock market index. Asian Economic and Financial Review, 5(2), 249-263. Retrieved from https://www.researchgate.net/ publication/298334132_Predictive_Power_of_Financial_Ratios_With_Regard_To_the_Turkish_Banking_Industry_An_Empirical_Study_on_the_Stock_Market_Index

18. Kabajeh, D. M., AL Nu'aimat, S. M. A., \& Dahmash, F. N. (2012). The Relationship between the ROA, ROE and ROI Ratios with Jordanian Insurance Public Companies Market Share Prices. International Journal of Humanities and Social Science, 2(11), 115-120. Retrieved from https://docplayer.net/20938028The-relationship-between-theroa-roe-and-roi-ratios-with-jordanian-insurance-public-companiesmarket-share-prices.html

19. Macharia, I. P., \& Gatuhi, K. (2013). Effect of Financial Performance Indicators on Market Price of Shares in Commercial Banks of Kenya. International Journal of Management \& Business Studies, 3(3), 72-77. Retrieved from http://www.ijmbs.com/33/ peter.pdf

20. Marangu, K., \& Jagongo, A. O. (2015). Price to Book Value Ratio and Financial Statement Variables (An Empirical Study of Companies Quoted At Nairobi Securities Exchange, Kenya). Global Journal of Commerce and Management Perspective, 3(6), 5056. Retrieved from http://ir-library. ku.ac.ke/handle/123456789/12137.

21. Maswadeh, S. (2016). Correlation between returns and market and book value per share. International Journal of Economics and Business Administration, 2(5), 45-52. Retrieved from https://ssrn. com/abstract $=2780059$.

22. Menaje, P. M. (2012). Impact of selected financial variables on share price of publicly listed firms in the Philippines. American International Journal of Contemporary Research, 2(9), 98104. Retrieved from http://aijcrnet. com/journals/Vol_2_No_9_September_2012/12.pdf_
23. Naïmy, V. Y. (2008). Financial Ratios and Stock Prices: Consistency or Discrepancy? Longitudinal Comparison between UAE and USA. Journal of Business \& Economics Research (JBER), 6(1), 41-50. https://doi. org/10.19030/jber.v6i1.2378

24. Pathirawasam, C. H. (2013). The Value Relevance of Earnings and Book Value: The Importance of Ownership Concentration and Firm Size. Journal of Competitiveness, 5(2), 98107. https://doi.org/10.7441/ joc.2013.02.07

25. Saymeh, A. A. F., \& Salameh, R. M. (2019). Factors affecting service share prices at Amman stock exchange. International Journal of Business and Management, 14(2), 149-159. https://doi.org/10.5539/ ijbm.v14n7p149

26. Shittu, I., Ahmad, A. C., \& Ishak, Z. (2016). Price to book value, price to sales multiples and stock price; evidence from Nigerian listed firms. Journal of Advanced Research in Business and Management Studies, 3(1), 85-93. Retrieved from http://repo.uum. edu.my/19498/

27. Wijesundera, A. A. V. I., Weerasinghe, D. A. S., Krishna, T. P. C. R., Gunawardena, M. M. D., \& Peiris, H. R. I. (2016). Predictability of stock returns using financial ratios: empirical evidence from Colombo stock exchange. Kelaniya Journal of Management, 4(2), 44-55. http:// doi.org/10.4038/kjm.v4i2.7500 